DOI https://doi.org/10.36059/978-966-397-173-5/36-52

\title{
THE SPACE OF THE CITY AND THE SPACE OF LIFE IN THE DISCOURSE OF SOCIAL PHILOSOPHY
}

\section{Hapon N. P.}

\section{INTRODUCTION}

One of the many human life projects is the city. It is a creative attempt of a person to adjust their own lifeworld to the heart's desires. When building a city, people not only materially and spiritually identify themselves, but also undergo world-view transformations. With its historical and cultural monuments the city forms a unique architectural landscape, which is the space of concentration of group memory for generations. The city's socio-cultural space is also a space for nurturing spiritual perspectives through contemplation of sacred buildings, monuments, artisticsights, etc. All of them are called to "increase the soul", to spiritualize life, to limit the spiritual qualities of people. At the same time, urban space is a space for the development of people's social perspectives (cultural, economic, political ones), and is the best platform for implementing democracy. Besides, urban space may reflect the stagnation of public freedoms or their decline.

The philosophy of the city has a long discursive history: the Platonic problem of the ideal state or policy, the utopian project oft he City of the Sun Campanella. Various philosophical reflections on the city are found in the works of "The City of God" and "The City of the Earth" by Augustine the Blessed, or in the reception of constructing classical rationality, following the example of the city in Descartes' Method Considerations, etc. Modern social philosophers, cultural scientists, sociologists show interest in urban social space, cultural, economic and political factors of its humanization. These are poblems of private and public space, intergroup relations, exchange of information and joint activity, deterioration of environmental conditions of living, conflict of public / private spheres and the resulting deformation of the surrounding space. Thereis a bunch of research conducted in the interdisciplinary discourse. In particular, the study on the subjective definition of urban distances by D. Lee, M. Kanter, on the evaluation of residents' urbanroutesby M. Rieland F. Lovental, on determining the degree of attractiveness of the citycenter by D. Rappapport. Researchers also found out the subjective assessments of the boundaries of urban neighborhoods, classified various objects (monuments, parks, squares, cemeteries, etc.) mental maps of the city (D. Lee, G. Spencer). Psychologists (S. Milgram, D. Gold) have considered the prevalence of suchmoral and psychological traits and 
mental states of urban dwellers as "anomia", "alienation", "apathy", "urban stress", etc.

The theoretical foundations of the study were the provisions on the cognitive aspect of the spatial perception of the city; they were outlined in the works of J. Bruner, B. Velichkovsky, S. Gabidulin, E. Lapin, and W. Nisser. The analysis of the problems of spatial human behavior (the theory of "places of behavior" by R. Barker), which were elaborated in the works by Y. Kruuswall, K. Leika, T. Neith and others is significant. The position of F. Vasilyuk, the philosopher, on the ontological construction of the "surrounding world" as an explication of the deep foundations of everyday consciousness was also noted. The provisions and requirements developed by psychologists for environmental in stitutions in educational, industrial, recreational and other settings, types of object-space environment (J. Barre, J. Boris, R. Boffill, J. Hirschler, J. Dreyfus-Ze, etc.) are also useful. The concept of situationalism (R. Ross, R. Nisbett, etc.), which examines the situation of subjectivity under the influence of a set of elements of the environment, was substantially important.

\section{Socio-philosophical problems of humanization of the city social space}

The dynamism of the modern Ukrainian social life of the city (rallies, folk venues, mass artistic sights, etc.) is reflected in the social space and makes it a social spectacle. However, the humanistic potential of the social spectacle is determined not so much by the concept of "crowded" as by the concept of "human". Urban space becomes a real sight if it is inhabited. The urban space, therefore, is a space of social spectacle that is open not only to seeing, watching, but also to empathizing, evaluating, responding and taking collective action to improve and inspire life. When we think of a spectacle, we always mean its spatial dimension, its landscape, what makes the spectacle visible, palpable. However, the spectacle can have different manifestations, namely, from the real physical to the mental and virtual ones.

Social space is an integral construct, an environment in which social relationships take place. It does not coincide with the physical, but the physical space can be commensurate with the social. There is a number of established approaches to understanding the nature of social space. The naturalistic approach considers social space through the properties of the body, matter (physical, chemical, geographical, organic reality). The activist approach defines it as a space of human activity, social processes. A substantialist vision of social space emphasizes individuals related to social connections. Representatives of the relationalist approach view social space as a system of structured social relations between people. Therefore, social space is a kind of space (along with physical and other ones); a multidimensional space of interconnected social processes, 
social relationships, social practices, social positions, and social fields. Social space can be described as a set of fields (for example, the field of culture, politics, economy, etc.) over which capital has a power.

Different types of capital (economic, cultural, social, symbolic ones) in the social space create its structure. The problem of urban space as a center where symbolic capital is crystallized is not new. The inhabited social space of the city is a symbolic capital. Paul Bourdie, the French sociologist and philosopher, singled out the three most common types of capital: economic, cultural and symbolic ones ${ }^{1}$. Economic capital is directly converted into money and secured by ownership. Cultural capital can be in three states: incorporated state (in the form of prolonged dispositions of mind and body), objective state (in the form of cultural goods that are a reflection or embodiment of a theory or their critique, namely, paintings, books, dictionaries, tools, machines, etc.)., institutionalized (in the form of objectification, such as educational qualifications). Cultural capital can be institutionalized through education and thus converted into economic capital. Finally, symbolic capital is related to the association of individuals into social groups through communicative action. Social power supervises, uses, increases or decreases capital in its forms. Symbolic human capital can be described as the deployment of communication between people who express confidence or distrust in the words and actions of the authorities. Communicative action as an expression of symbolic human capital is unthinkable without urban space-place. It represents the symbolic capital in its varieties of mass communication on the squares, streets, stadiums, concert halls, etc. These spatial zones of mass communication can be analyzed with the help of aesthetic, communicative, temporal criteria resulting in the height and configuration of the space in which society, etc. are currently inscribed.

The strength that causes the division of the previously shared living space of the city and creates spectacles or involuntary venues of protest is power. The latter is not only a deep cause of any division of the city's spatial zones. The authorities carefully nurture and protect the space of social communication, where symbolic capital is produced. From time to time, the authorities mark the social space of the city, build or destroy city monuments, display their "border signs" that reinforce the power narratives (for example, concern for the people). The authorities are using the social space to develop artistic spectacles: celebrations of various anniversaries, concerts and more. In general, the socio-symbolic space of the city is saturated with various forms of

${ }^{1}$ Бурдье П. Социология социального пространства; пер. с франц.; отв. ред. перевода Н.А. Шматко. М.: Институт экспериментальной социологии; СПб.: Алетейя, 2007. C. $85-86$. 
struggle for self-assertion. Anything that is potentially or realistically capable of spilling over into a spectacle is controlled by a government that is trying to participate in the spectacle directly or indirectly. Yevgeny Dukov, the Russian scientist, states that the civil society should ask the authorities for permission to hold not only rallies, marches, demonstrations, but also all artistic shows ${ }^{2}$.

Michel de Certeau, the French culture studies expert, considers the urban space as a place of struggle between the "tactics" and "practices" of the authorities' social agents. Particular attention is given to de Serto's distinction between "strategy" and "tactics". It connects the concept of "strategy" with institutions and structures of government, but instead "tactics" it uses a personality to create free personal space in an environment defined by strategies. The author notes that the view of the city from above, from the real heights (a skyscraper) or imaginary ones (maps, paintings, projects) is different from the real life in the city. It is a matter of tactics for the development of space by the inhabitants, which oppose the urbanistic order. Particular attention is given to Michel de Certeau's"grassroots" ways of "appropriating" pedestrians, describing the relationship between semiotic and spatial practices (through myths, stories, memories of places). On the example of the verbs "walk", "browse", "name" the city where Serto views urban space as a place of struggle of "tactics" and "practices" of government social agents ${ }^{3}$.

The struggle for power takes on specific forms in the part of the social space that is associated with a particular form of socio-cultural activity, with an "artistic spectacle". It is not so much about the right to organize festive concerts by the authorities, but about enhancing mass communication, communicative capital through artistic spectacles. The expression of the conflict between the authorities and the people in the city is the deprivation of the right of their unworthy authorities to equip the space of artistic spectacles. The right of the authorities to the city, to its space is not only manifested as the right to organize artistic shows. The government manages the necessary link between urbanization and the production as well as the use of additional revenue. Democratization of this right and the construction of a broad social movement that embodies its will is necessary. It becomes possible if the urban community wants to regain control and establish new ways of urbanization. Henri Lefebvre rightly noted that the revolution must be urban in the broadest sense of the word or not at all ${ }^{4}$.

${ }^{2}$ Дуков Е. Зрелище как социальный феномен. Телескоп: журнал социологических $u$ маркетинговых исследований. 2010. № 3 (81). С. 25.

${ }^{3}$ Серто де М. Изобретение повседневности; пер. с фр. Д. Калугина, Н. Мовниной. СПб. : Изд-во Европейского университета, 2013. С. 41.

${ }^{4}$ Лефевр А. Социальное пространство. Неприкосновенный запас. 2010. № 2 (70). URL: Режим доступу: http://magazines.russ.ru/nz/2010/2/le1.html 
It is the analysis of specific social practices of urban space that allows one to depart from space as a certain passive, static surface and to comprehend it as the space of capitalism. It is a socio-cultural space of historical, sacred monuments, squares, etc. that colonize and consume, buy and sell, create and destroy, use and devastate, for which they are being tried and fought. Nowadays the most striking examples of these processes are revealed through the analysis of the structure of modern cities. The space of the city embodies the contradictions of the social order as the contradictions of capitalism are the contradictions of space.

In a society that departs from the colonial heritage, the city is in the process of splitting into separate parts, fragmenting it whereas numerous "micro-states" are formed. For example, the social space of the city center is made up of affluent neighborhoods with closed schools, tennis courts and private security. The outskirts of the city have a different, social "landscape". Capital makes the city fragmented. Under these circumstances, it becomes more difficult to adhere to the ideals of urban identity, citizenship and belonging. Even the idea that a city can act as a collective political body, a place where progressive social movements can take place, seems impossible. In spite of this, there are urban social movements that seek to overcome the isolation of neighborhoods and give the city space a different form than that promoted by developers supported by financial, corporate capital and local government.

The work by David Garvey, the anthropologist, entitled The Right to the City states that the absorption of capital surplus through the transformation of the city has a darker side than the fragmentation of space, which hinders the formation of urban identity of citizens ${ }^{5}$. This is achieved by "osmanization" of the social space of the city. It is about reorganizing cities through "creative" destruction. Osmanization is associated with the name of George Emil Osman, the architect, as a practice of reshaping urban space. Following the instructions of Napoleon III in the second half of the nineteenth century he practically destroyed most of old Paris, demolished many medieval houses and laid new boulevards. The author of the idea of controlling the social space by the authorities intentionally initiated the eviction of a large part of the workers, poor burghers from the city center, where they threatened public order and political power. It took more than a hundred years to complete the "depopulation" of downtown Paris. The consequences of this are now being seen in the unrest that takes place in the isolated suburbs of marginalized immigrants, the unemployed and the young.

\footnotetext{
${ }^{5}$ Гарві Д. Право на місто. Спільне: журнал сочіальної критики. 2010. № 2. С. 9.
} 
The "depopulation" of the city center space as a result of the process of demolition of old buildings and the eviction of residents on the outskirts is a pressing problem. The process of "depopulation" of the city center, compaction of the ontology of the city is the actual commercialization of space, with the overriding of the right of power to the artistic spectacle. It would seem that the space of the city center is inhabited because it is crowded with people. However, in reality, the space of the city center is most represented by people with fluid identity. These are tourists, gawkers, business workers, whose short duration of stay in the city and cultural integrity is obvious. The boundary between the reputation of an artistic or social spectacle and its humanity lies in the difference between contemplation and creation.

Taking over the right to an artistic spectacle by the business authorities currently means the commercial capture of public spaces, squares, and the like. Sculptures, fountains, foundations of the historic center are being sheltered by owners of cafes, restaurants, etc. and they are becoming less accessible to the city residents, including young people. Besides, the process of conditional or real displacement from the social space of the city by representatives of youth subcultures, who gather around monuments, fountains, squares is taking place. The latter are structural components of the static artistic space of the city, a kind of an "open-air museum". The social space of the city center as a static artistic spectacle was receiving its dynamics and formed symbolic capital through youth communication, in particular. Each city has a space that marks youth as their right to their own artistic spectacle; however, it conflicts with the authorities because of this right. The displacement of young people from the city center, especially from a space that has the status of a static artistic spectacle, always has negative consequences for the authorities, increases the resistance and protest potential of the urban surroundings. Instead of expanding an inhabited and animated urban space, where artistic monuments are located, where artistic life thrives and mental qualities are formed, the authorities provoke its diminution, "depopulation" by the processes of fragmentation and urbanization of urban space.

Psychological meanings given to young people by the social space of the city as an artistic spectacle do not currently correspond to the real social grouping of young people in this space. The reasons for this discrepancy are the involvement of the mentioned mechanisms of the capital-power struggle for the social space of the city: the restoration of the right to the artistic spectacle, the fragmentation of the urban space and its "Ottomanization" (destruction of monuments and resettlement of residents). The onset of commercialized space in the youth grouping of social space in the city that 
was previously free is an attempt to "depopulate" the public space. It is the displacement of informal groups that, through their localization near the monuments, created a space not only for "otherness" but also for diversity. It is this localization in the space of informal youth that has been read ontologically is threatening with undemocratic discourse. In fact, the fear of the authorities on the diversity of the youth world, its further unification, turns to the depopulation of the social space in the city center.

Space is not desolate in the sense of reducing the number of people in space, but in the sense of fragmenting the ontology of the city. Perhaps the time has come for a new reading of the notion of "citizens", releasing the old ontological principle. "To fence" means to detach, to separate space from nonspace. Under the influence of such detachment of their space from the space of another, the right of young people to the city centers as an artistic spectacle is threatened. Young people who are always searching for their own identity change their location in the city space if the symbolic space is alienated. The gaps of the newest arrangement of the informal youth of their own "social" space are Internet space, unfinished buildings, cellars, and deserted outskirts of the city. This situation of transgression of the life of a part of the youth, going beyond the city limits as an artistic spectacle outlines a significant problem of youth education. It is not just about finding new motivating factors and aesthetics for youth through the perception of the city's architectural monuments, expanding and deepening young people's awareness of the city's cultural history. The question remains about new ways of educating young people as responsible citizens through organizational and meaningful activities of guardianship, care, respectful treatment of city monuments, asserting their space of communication and organization of artistic spectacle.

\section{The space of life and globalization in the philosophy of post-structuralism and post-colonialism}

In the poststructuralist discourse of the second half of the twentieth century it was noted that the movement of classical texts through the textual ages is, in fact, a cultural migration. This process provides textual inheritance. For instance, Freud, who referred to the ancient text of Sophocles, on the myth of Oedipus, interprets and uses it to explain the psychological phenomena of the modern human world, though mostly female. K.-G. Jung generalizes Freud's theory, diversifies it with the notion of archetype as a collective unconscious and archetypal images of anime / animus. E. Fromm focuses on the socio-cultural and psychological markers of the male / female world. The most prominent is the theme of cultural migration in landmark texts. J. Derrida underscored Western logocentrism, with its inherent dichotomous concepts (being / nothing, presence / absence, mind / matter, 
man / woman, etc.), developed with a reliance on the idea of sonship (as an exchange of the Word between a father and a son) ${ }^{6}$.

In herwork "Posthuman" R. Braidotti represents the multiplicity of the image of a man in the time of globalization and fragmentation, increasing influence on the human psyche, information and biological technologies. Such loss of unity of the perceived subject should not dissuade the researcher. Posthuman helps us understand "the meaning of our flexible and multiple identities"7. Posthuman expresses the transformations of human subjectivity and physicality under the influence of a market economy, commercialization, the production of genetically modified organisms, which are slowly and gradually blurring the categorical differences between humans and other species of the living. Today he presents a number of changed types of identity of a "pilgrim" ("dreamer", "whore", "tourist", "player"), which are different epistoms of nomadism. The concept of "nomad" as a key subjectivity is now considered in the work Transpositions: On Nomadic Ethics (2006) by R. Bridotti.

On a more general level, the history of cognition is always a nomadic story. The nomad figure allows Brydotti to reflect on the dissemination of ideas beyond borders, not only on the basis of the traveler's leading model, but also in the form of preserving ideas that may be condemned to collective amnesia. Braidotti seeks to show that nomadic consciousness is similar to what Foucault calls counter-memory; it is a form of opposition to assimilation or homologization by dominant modes of self-representation ${ }^{8}$. Critics dwell on the negative nomadic characteristics, particularly those acquired by modern countercultures, referring to the atrocities of migrant protesters (mainly in urban metropolitan areas). R. Braidotti convinces the opponents that there is a link between the violence of state apparatus and the neonomadism of group atrocities. An important metaphorical model to help understand the origins of nomadic violence is the historical "opposition to the city and the vastness of the desert." The city is diametrically opposite to the open shepherd's space: Nomos, or land, is the etymological root of a nomad, which means an elder who oversees the definition of a pasture for a tribe 9 . Deleuze noted that laternomos began to mean law. Nomos stands for the principle of land division and constitutes opposition to the power of the policyas such. Thus it appears as a space "... without fences and borders;

${ }^{6}$ Деррида Ж. О почтовой открытке от Сократа до Фрейда и не только. Минск : Совр. литератор, 1999. С. 17.

${ }^{7}$ Braidotti R. The Posthuman. Cambridge: Polity Press, 2013. P. 18.

${ }^{8}$ Брайдотти Р. Путем номадизма. Гендерные исследования. Харьков: ХЦГИ, 2000. № 4. C. 30 .

${ }^{9}$ Ibid. 
herding, open, nomadic space, in contrast to which the settled power of the city was being reproduced. The Metropolis Space Against Nomadic Trajectories"10. Braidotti's spatial metaphor enables her to carry out a retrospective analysis of the nomadic violence problem, the riot of rallies on the streets of metropolitan areas, and to approach it ambivalently. Braidotti uses the nomad figure as a form of entry into the debate about the postmodern crisis of value. As a follower of Deleuze's views and post-structuralist theorist, she expressed her skepticism about the "decline" of culture, which so many philosophers of "high" or "late" modernity have spoken about (J. Vattimo, J. Habermas, etc.). She believes that the crisis cannot occur at the same time as the emergence of numerous socio-cultural movements and women's community initiatives in Western Europe in the 1970s. In Patterns of Dissonance ${ }^{11}$ Braidotti was critical of neo-positivism. Adherents of Foucault's philosophy, Deleuze, have little chance of theoretical priority. Braidotti points out that their philosophical style, radical consideration of issues, their interest in changes and transformations in everyday life are suppressed in Europe by the philosophical currents of neo-positivism.

This means that the space that holds post-structuralist thinking is the space of the "outskirts of the city", the periphery of philosophy ${ }^{12}$. A sense of the need for a researcher not to identify himself with a sediment of thought, a monologue, and intellectual conventions in the philosophy of thinking must be essential for finding a philosophical space in a post-structuralist direction. The theory that defends the form of the creation of new ways of thinking (J. Deleuze, J.-J. Derida, L. Irigieri) evokes Braidotti's hilosophical commitment. She is interested only in such systems of thought or conceptual constructions, which are able to open perspectives of philosophical reasoning about the modern changes of subjectivity, which occur under the influence of global socio-cultural transformations. It is her nomadic project of thinking that gives grounds for modern researchers to assert its positive force. Changes in the historical situation, the globalization associated with the emergence of a transnational economy, the migration process, encourage exploration of new spaces where new identities of subjects and groups are produced.

Let us follow Braidotti's speech style to come up with strategies that define the spatial metaphor of "nomadic thinking". Thus, Braidottistates that the nomad researcher despises "mainline" communication, because these "corks" of meanings at "entrances to the city" (a logocentric text) create a

\footnotetext{
${ }^{10} \mathrm{Ibid}$.

${ }^{11}$ Braidotti R. Patterns of Dissonance. Cambrige: Polity Press. New York: Roultedge, 1991. $315 \mathrm{p}$.

12 Брайдотти Р. Путем номадизма. Гендерные исследования. Харьков: ХЦГИ, 2000. № 4. C. 32-33.
} 
special form of "contamination" of thinking (stereotypes) for the reader". The nomadic letter rushes into the desert: into silence between official cacophonies, flirting with radical irrelevance and segregation" ${ }^{\prime 3}$. The author believes that the meanings and definitions that were born in modern science are often meaningful "corks" that interfere with the socio-cultural phenomena of the present. Just like the official monolithic theories that "clog" many phenomena, relations between the sexes. Talking about gender without dichotomy (domination / submission) within the concepts of metatheories is difficult. To deny metatheory is to follow the path of "whiny-warlike feminism", which will mean the loss of "common sense." "Departure from the city" ("deteritization"), which is associated with the androcentric territory of textuality (the city-state of Logos) to the "desert" is better than "laying siege" to an invincible fortress (tradition of logocentric writing, text), or "To stand under the gate" with the hope that it would be opened voluntarily ${ }^{14}$.

Braidotti considers a desert as the territory of the "nomad" (author, philosopher), where it carries all the previous experience of residence. As an intellectual style, nomadism allows for the cultivation of an "oral history" that has always been preserved by women as opposed to a "written history" by men. Oral history has been able to escape the pressure of the Letter, just as a linguistic subject emerges from responsibility, power, and conceptual canons. In reasoning, the nomad (author) cannot be demarcated and grounded in a single, basic territory (theory). It is equally a waste of responsiveness (analysis) to a new socio-cultural situation. It is necessary to move among different theories, discourses, to be a nomad. "Nomad maps need to be constantly redrawn, and as such they are structurally opposite to real estate and predatory consumption" ${ }^{\prime 15}$. The philosopher points to the peculiarity of the nomadic style of thinking, that is, to perceive any theory, to feel it, but not as its own settled plane. In Nomadic Subject R. Braidotti provides examples of the opposition value of the new "visual culture" presented by the nomadic creator. This contemporary author (s) is a migrant or immigrant, a marginalist who creates the so-called "arts of resistance" through his narratives overcoming the post-colonial power that feeds on the processes of globalization. Therefore nomadic creativity is an important factor in exploring personal, cultural, and political transformations through new technologies of visual representation and artistic imagery. Migrants' dissatisfaction with social ties, their disconnection from the full-fledged spheres of social life, and

${ }^{13}$ Брайдотти Р. Путем номадизма. Гендерные исследования. Харьков: ХЦГИ, 2000. № 4. C. 20 .

${ }^{14}$ Ibid.

15 Брайдотти Р. Путем номадизма. Гендерные исследования. Харьков: ХЦГИ, 2000. № 4. C. 39 . 
from the official spaces of society into which they have been forced to flow into global flows, make them seek though the spaces that are marked by a policy (post-industrial city), but are vacant. Such privileged areas for the art of artists' resistance (Graffiti, various installations) are underground passages, subway stations, crossings, bridges, waiting rooms, premises of freight departments, airports and more. "Public spaces are the zones that mark the transition rituals and subordination to such cultural and specific imperatives as schedules, production rhythms, permitted and prohibited directions, loading and unloading, places of transition, space of transformations. Space is an abstraction governed by the logic of a market economy, and as such it is "imbued with social relations" $"$. In public spaces, in areas of human flow installations carry not only creative forces but also political goals.

However, the meaning of the nomadic research project reflects the need to explore and construct new types of subjectivity that exist as marginal ones. Their emergence as new subjects of desire, presenting themselves through the so-called "visual culture", the art of resistance is evident. The new types of subjectivity generated by global migration processes also require new social and symbolic structures capable of discerning changes in their personalities, needs and desires in order to be represented socially and collectively. The perspectives of such discourse are obvious, and the theme of the dramatic experience of "exile" and "voluntary-forced" withdrawal from socioculture is relevant at the time of economically conditioned migration of male / female bodies. Researchers working within the nomadic project are tasked with tracking down these new types of male / female subjectivity.

In Braidotti's view, identification, in particularly female one, with exile economic-driven emigration should be a pivotal topic in contemporary gender studies. The traditional judgment about the only type of female subjectivity, female typological identity, is changing. The research focuses not only on the position of women in their own ethnic culture, the state, but also on the problems of differences between women, taking into account their migratory status. At the end of the twentieth century Europe is confronted with the massive exodus of people (especially women, the young) from countries experiencing crises and wars. Migration and exile issues, the right to social and cultural involvement, entry and asylum are all addressed by gender studies. The spatial metaphor of Braidotti's philosophical work makes it possible to grasp the "contours of geographical territories and cultural spaces" from the perspective of experiencing the subject of its marginality. The work is a new textual model of exploratory nomadic subjectivity, the deconstruction

${ }^{16}$ Брайдотти Р. Путем номадизма. Гендерные исследования. Харьков: ХЦГИ, 2000. № 4. С. 24. 
of racial and gender stereotypes, and the formation of multiculturalism and national tolerance. The spatial metaphors of the text allow her to problematize female subjectivity and identity multifaceted, the variability of which is conditioned by the global migration process. In this way, the researcher will be able to "catch" new types of gender subjectivity generated by the global migration process. They require new symbolic means capable of noticing personality changes (needs, desires) in order to represent them socially and register collectively.

The post-structuralist project of nomadic subjectivity of the European philosopher R. Braidotti, which was formulated under the influence of J. Deleuze's ideas, has a similar development in post-colonial discourse (F. Fenon, E. McClintock, E. Said, etc.). In this sense, analysts consider that R. Mohanram's philosophical work Black Body. Women, Colonialism, and Space $(1999)^{17}$ is evidence of the effective application of the concept of nomadic thinking within a postmodern discourse that integrates the ideas of ethnic, diasporic, and postcolonial studies with studies of women's identity and theory of power. In his work, Mohanram employs a nomadic cognitive setting, uses multiple methodologies, and is not grounded in any of them: Freudianism, Levi-Strauss structuralism, Merleau-Ponty phenomenology, Locke's "social contract" philosophy. Such methodological tool is a good indication that female subjectivity and identity can be viewed not only in a one-liner but also in a multivariate way.

In the line of Deleuze and Braidotti's approach, nomadicism is an extremely convenient research cognitive setting that allows one to respond, describe and explain reality dynamically. Thus, "as a figure of modern subjectivity, the nomad is a post-metaphysical, intense, multiple entity that functions in a network of relationships. It cannot be reduced to a linear, teleological form of subjectivity, but rather it is a domain of multiple connections. It is corporeal, thus cultural; as an artifact, it (s) is a technological mix of human and post-human; it is a complex set, endowed with numerous interconnectivity in the non-personal mode... It is abstract, but at the same time absolutely, operationally real" ${ }^{18}$. One of the epistemological tasks of nomadic research subjectivity is the restoration of a sense of intersubjectivity, which has been protected by the feminist epistemological stance on the objectivity of cognition. This gives the opportunity to understand and verify the adequacy of theory for the community of subjects,

\footnotetext{
${ }^{17}$ Mohanram R. Black Body. Woman, Colonialism and Space. London; Minmeapolis: University of Minnesota Press, 1999. 328 p.

${ }_{18}$ Брайдотти Р. Путем номадизма. Гендерные исследования. Харьков: ХЦГИ, 2000. № 4. С. 39 .
} 
to depart from its subjective independence as a false requirement of truth ("neutrality" of truth from any conventions).

The nomadic (mobile) cognitive setting allows the researcher to grasp the space in which the postcolonial subject resides through spatial metaphors. Due to the spatial metaphor of discourse, women and men are enriched with content, new aspects of vision. In the works of M. Heidegger, M. Foucault, J. Deleuze, the tradition of spatial metaphor in philosophy develops, where metaphor is perceived as a form of concept existence, and its essence is realized at the level of intuitive thinking much better than at the level of rationality. Philosophical analysis of the prerequisites and conditions of the process of thinking, the phenomenon of consciousness, the formation of subjectivity, automatisms of perception were often based on the data of visual experience and operated in the following categories: "space", "picture of the world", "form", "images of consciousness", "intellectual contemplation" etc. However, these philosophical metaphors often seem "homeless" in the world of philosophical abstractions, their visual status is not particularly taken into account, and they are used as rhetorical concepts that have illustrative value for knowing the "invisible" truth. However, the visual originality of the Western philosophical tradition may be somewhat different. The Gestalt or O. Spengler's symbol is a spatial metaphor, though its content is rather planartopological. It is worth mentioning J. Bataille with his "transgression", Merlot-Ponty with his transcendental geology, and others. In general, spatial metaphor makes the visual, expressive interconnection of thought and physicality, territoriality. The work of A. Levefre, The Production of Space (1974), is also devoted to the analysis of space as a place for the deployment of social practices. The spatial metaphor, Nomadic Subject, is also evident in R. Braidotti's work. Recent post-colonial "cognitive policies" often track the spatial metaphor of gender-related texts. An example is R. Mohanram's philosophical work Black Body. Women, Colonialism and Space (1999).

It is noteworthy to state that the hierarchy and tendency towards sociocultural dominance are textually related to "vertical" spatial metaphors. Discursive speech practices have many examples of "topological" metaphors at the same time: planes, lines, landscapes, and so on. The appeal to the image-concept of the line of life, its "bending", "folds" are common in the writings of Western researchers (Deleuze, Vidal). A new spatial form of the concept of the "Superhuman" is emerging, which is perceived as nomadic singularity, the dynamic unity of the singular and the plural, which moves the "super folded surface" of life and at the same time shapes it by its motion. Feminine and masculine postcolonial identity is more fully depicted in the spatial model, "stay-in-space", immersion in the environment, landscape. For example, Mohanram offers his dimension of "volume", "capacity" as a 
philosophical category. It correlates the black marginalized body (female symbol) with the southern hemisphere and the visual images of nature, and the white body colonial power (male symbol) with the northern hemisphere of the Earth, which retains a planar vision of alienated from the corporeality of categories, namely, knowledge and concepts. The author constructs a text of work on images-concepts of southern emotional identity and rational northern. Mohanram apparently finds this synthetic mode of speech practice as a "nomadic" subject, as a contemporary intellectual writer who migrates and "immerses" in the social space of India, New Zealand and the United States. In this case, the metaphors of identity of the subject include cognitive characteristics of spatial relations, such as status, position, situation, degree of distance from the center and the level of marginalization, kinesics, the principle of spatial restriction, etc. Just a feminine body, designated by Freud as a "dark continent", and Plato in "Timaea" as the nameless and faceless "Something", located in Mohanram's vision at the intersection of terrain, race, and gender, is an ideal plane for spatial imperial-masculine incarnations ${ }^{19}$. In this context, the author gives an example from the epoch of the formation of British colonial identity of the eighteenth century, which was carried out through the imperial seizure of geographical spaces-bodies, and through the juxtaposition of the center and colonies. In directing them to new territories, "British masculinism localized British women as a constant," turning them into a ground that was the turning point of male exteriorization into the world. By comparing the home ("the British woman's spatial body") and the world (the "gender-racial body of the colonies"), an opposition of the dominant masculine Subject and the colonized feminine Other formed ${ }^{20}$.

It is noted by gender analysts (V. Sukovata) that the space of a woman certainly embodies the discourse of power, which is created by different conceptual means: logically-social (Locke), psychoanalytic (Freud), corporeal-metaphorical ones (Fenon). Each locality, territory, land creates its own contours of differences through its special "bodily" landscape and "bodily" existence. The desire to build a methodology of "corporeal" philosophy, to affirm "personal sensory experience, subjectivity of the body" as a scientific analysis motivates modern researchers of the post-colonial ${ }^{21}$. In his essay "Algeria without a burqa", F. Fanon acknowledged that in colonialism women act as symbolic mediators. Colonialism redefines the labor and sexual economy of the people in order to turn women's power into

19 Суковатая В. Солнце “черного цвета": Postcolonial-ные познавательные политики эпохи Постмодерна. Гендерные исследования. Харьков: ХЦГУ, 2000. № 4. С. 337.

${ }^{20}$ Суковатая В. Солнце "черного цвета": Postcolonial-ные познавательные политики эпохи Постмодерна. Гендерные исследования. Харьков: ХЦГУ, 2000. № 4. С. 336.

${ }^{21}$ Ibid. 
colonial hands and undermine the patriarchal power of colonized men. The study of the cultural intersection of gender and the nation is a major theme of F. Fanon, whose vision of the national factor is an integral part of his theory of anti-colonial resistance.

Globalization processes have given rise to the magnitude of the problem of nomadic subjectivity associated with voluntary-forced migration. "Exile policies" is one of the main terms used by Mohanram in his work Black Body to define how the geography of life practices manifests itself in relation to other bodies. The prospects for problematizing nomadic subjectivity are obvious. The theme of nomadism, that is the dramatic experience of "exile" and "voluntary-forced" withdrawal from socioculture, is relevant at the time of economically conditioned migration of male-female bodies especially when it comes to the author's attempt to delineate the contours of geographical and cultural spaces from the positions of a subject whose identity emerges from the sense of his "black body". The body does not have to be actually black; "blackness" becomes a marker of the white body, if it becomes out of its own socio-cultural context of the place. Body is a guaranty of subjectivity, designation of origin (race, nationality, poor / rich country). It also contains markers of space as a product of socio-political relations, center / outskirts, emigrant, etc.) The forced migration of bodies into another socioculture causes such a body not only to marginalize, but also to challenge micropoliticians. After all, it is easier to trace the body, to catch it because of its "blackness", where color is a symbol of "otherness", something dangerous for Western traditional culture and morality. The "black body" of the migrant undergoes various micropolitics of power: from the escalation of mass moral panic (which favorably camouflages the mistakes of the authorities), to repressive "nudity" and "immersion" in mass media, or in myth-narrative abstractions ${ }^{22}$. "Black body" is an entity that is displaced from the space of culture. If the male or female body ceases to be perceived within the limits of subjective differences, then it becomes an object, impersonal or perverse sign.

\section{CONCLUSIONS}

Dynamic processes of social life of the present-day Ukrainian city (rallies, folk venues, mass artistic sights, etc.) make the urban space a venerable social spectacle. This inhabited urban space, as a space for social spectacle, is open to view, empathy, appreciation, response and responsible collective action to improve and inspire life. The process of humanization of urban space with its humanistic potential is opposed by the process of humanization. The latter is

${ }^{22}$ Суковатая В. Солнце “черного цвета": Postcolonial-ные познавательные политики эпохи Постмодерна. Гендерные исследования. Харьков: ХЦГУ, 2000. № 4. С. 338. 
shaded by the strategies of influence of the capital-power in the absence of collective responsibility, in particular of the urban communities. Desolation manifests itself in strategies such as the fragmentation of social space, the anonymization and unification of the diversive communicative culture of the city due to the prohibition of artistic spectacle and the displacement of subcultures from the urban environment. Only a synthesis of cultural and civic attitudes will enhance symbolic capital, the influence of communities, youth movements on capital-power, and help to humanize the process of "gentrification" (ennobling) of city space. This process can actually improve the quality of life of residents of certain areas of the city, but not at the cost of establishing new boundaries in urban space (between prestigious areas and no-go areas) and the brutal expulsion of poor and marginalized groups from urban space. The impetus for this process may be urban social movements, which will contribute to the transformation of the city into the space of an inhabited social spectaclein case of a responsible collective action. The problem of nomadic subjectivity has its origins in Deleuze's philosophy and is dealt in two ways by R. Braidotti's post-structuralist project. The first is related to the elucidation of socioscultural circumstances of the emergence of a new type of subjectivity, the second is the need for approval in the research plane nomadic (mobile) cognitive set. One of the main goals of the project is to restore epistemological intersubjectivity, which enables researchers to create a new gender concept through recognition of ethnic, national, and political differences. The nomadic subjectivity of the modern researcher will enable him to identify, on the one hand, from the androcentric monologism of knowledge with the inherent gender blindness and from the intellectual conventions of feminismon the other hand. In this way, the researcher will be able to "catch" new types of gender subjectivity generated by the global migration process. R. Mohanram's work Black Body. Women, Colonialism and Time, conducted within postcolonial studies, demonstrates the need for new symbolic means capable of noting the onset of the imperial globalization world and counteracting the tendencies of marginalization of subjectivity and loss of national identity.

\section{SUMMARY}

It is proved that the process of humanization of the urban space with its humanistic potential resists dehumanization process. This process is shown in the fragmentation of social space, and haussmannisation and unification of diverse communicative culture of the city. Opposition to dehumanization process is synchronization of the civil activity and solidarity. Influence of the communities, urban youthful movements on capital-power will help to humanize the process of subtilizing the city space. The paper analyses the application of Deleuze's philosophic visions, concepts and principes in theoretical and methodological plane of the modern gender project of 
R. Braidotti's "nomadic subjectivity". The work of Monhandram is a new textual model of exploratory nomadic subjectivity, the deconstruction of racial and gender stereotypes, and the formation of inter-ethnic tolerance. The spatial metaphors of the text made it possible for the author to reflect women's postcolonial subjectivity and identity, the variability of which is conditioned by the global migration process, in a multifaceted way.

\section{REFERENCES}

1. Брайдотти Р. Путем номадизма. Гендерные исследования. Харьковb: ХЦГИ, 2000. № 4. С. 18-45.

2. Бурдье П. Социология социального пространства; пер. с франц.; отв. ред. перевода Н.А. Шматко. М. : Институт экспериментальной социологии; СПб.: Алетейя, 2007. 288 с.

3. Гарві Д. Право на місто. Спільне: журнал соичіальної критики. 2010. № 2. С. $8-12$.

4. Деррида Ж. О почтовой открытке от Сократа до Фрейда и не только. Минск : Современный литератор, 1999. 832 с.

5. Дуков Е. Зрелище как социальный феномен. Телескоп: журнал социологических и маркетинговых исследований. 2010. № 3 (81). C. 24-28.

6. Лефевр А. Социальное пространство. Неприкосновенный запас. 2010. № 2 (70). URL: Режим доступу: http://magazines.russ.ru/nz/ 2010/2/le1.html

7. Серто де М. Изобретение повседневности; пер. с фр. Д. Калугина, Н. Мовниной. СПб.: Изд-во Европейского университета, 2013. 330 с.

8. Суковатая В. Солнце “черного цвета": Postcolonial-ные познавательные политики эпохи Постмодерна. Гендерные исследования. Харьков: ХЦГУ, 2000. № 4. С. 336-340.

9. Braidotti R. Patterns of Dissonance. Cambrige: Polity Press. New York : Roultedge, 1991. 315 p.

10. Braidotti R. The Posthuman. Cambridgeb: Polity Press, 2013. P. 67.

11. Mohanram R. Black Body. Woman, Colonialism and Space. London; Minmeapolisb: University of Minnesota Press, 1999. 328 p.

Information about the author: Hapon N. P., Doctor of Philosophie, Professor at the Department of Psychology, Ivan Franko National University of Lviv 1, Universytetska str., Lviv, 79000, Ukraine 